\title{
DMU40 MEGMUNKÁLÓ KÖZPONT VIZSGÁLATA III. NUMERIKUS MECHANIKAI VIZSGÁLAT
}

\author{
Kiss Róbert \\ tervezömérnök, Diehl Aviation Hungary Kft. \\ 4300 Nyírbátor, Ipari Park utca 9, e-mail: robert.kiss9405@gmail.com \\ Szilágyi Attila \\ egyetemi docens, Miskolci Egyetem, Szerszámgépészeti és Mechatronikai Intézet, \\ Szerszámgépek Intézeti Tanszéke \\ 3515 Miskolc, Miskolc-Egyetemváros, e-mail: szilagyi.attila@uni-miskolc.hu
}

\begin{abstract}
Absztrakt
Jelen cikk egy hosszabb kutató-elemzö munka része, ugyanis az elvégzett munka föbb pontjain keresztül vázolja fel a vizsgált tématerületnek és az alkalmazott módszernek megfelelöen a vizsgálat során kapott eredményeket, következtetéseket. A kutatás központi témája a szerszámgépek dinamikai merevsége, illetve meghatározásának különféle módszerei. Korábbi cikkünkben bemutatott analitikus úton történö vizsgálatot követöen most egy másik módszer kerül elötérbe, ugyanis egy CAE szoftver segitségével szintén elvégezzük a korábbi vizsgálatokat szimuláció formájában. A kapott eredményeket pedig összehasonlítjuk a korábban, analitikus úton meghatározott értékekkel.
\end{abstract}

Kulcsszavak: ANSYS R19, CAE, dinamikai merevség, modálanalizis, sajátfrekvencia, VEM

\begin{abstract}
This article is part of a longer research-analytical work, because it outlines the results and conclusions of the study according to the main topic of the research and the applies method. The central theme of the research is the dynamic stiffness of machine tools and the various methods for their determination. After analytical testing, we will deal with another method, because we also use $C A E$ software to perform previous tests in the form of simulations. The results obtained are compared with the values previously determined analytically.
\end{abstract}

Keywords: ANSYS R19, CAE, dynamic stiffness, modal analysis, natural frequency, FEM

\section{Bevezetés}

Cikkünkben egy hosszabb kutató munka [1,2] részeként ezúttal a numerikus mechanika eszközeinek szerszámgépek vizsgálata során történő alkalmazhatóságát mutatjuk be. A szerszámgépészeti konstrukciós feladatok egyik leggyakoribb esete a végeselem-módszerre (VEM) alapozott szerkezeti analízis. A gépészeti konstrukciós tevékenység során szerkezeti analízis alatt a mechanikus elemek vizsgálatát értjük, amelyet elvégezhetünk pl. a konstrukció egy konkrét alkatrészére (hajtókar), vagy részegységére (eszterga gépágya vagy marógép gépállványa), vagy adott esetben akár magára a berendezés egészére is. A számításoknál elsősorban az elmozdulásmezö meghatározása a cél, amelyekből további mennyiségek származtathatók, például a deformációk, a feszültségmező vagy a reakcióerők. 
Az általunk alkalmazott CAE szoftverröl, az ANSYS Workbench R19.1-rôl általánosságban elmondható, hogy rendkívül összetett felépítésü mérnöki programcsomag, ami az iparban széleskörben alkalmazható a nagyszámú szimulációs lehetőségeinek köszönhetően.

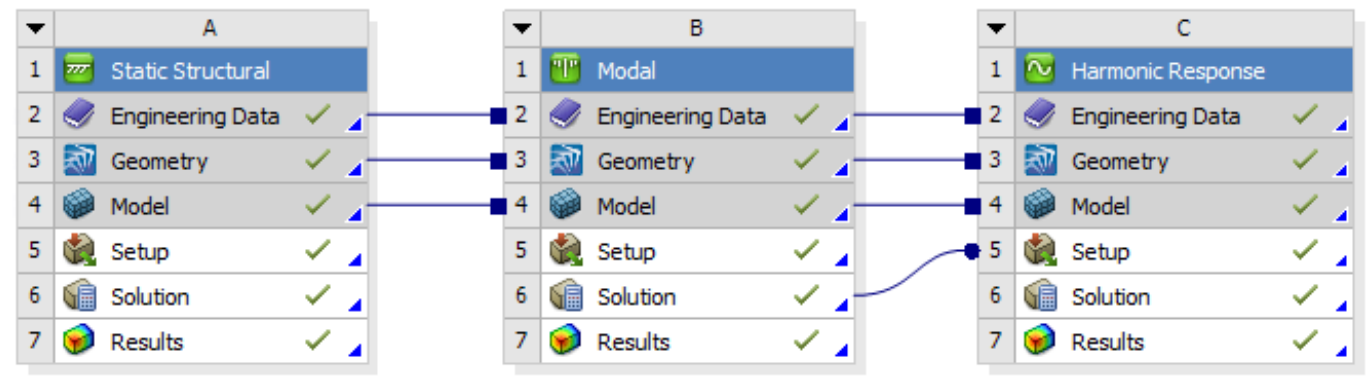

1. ábra. A szerszámgép 3D-s modelljére alkalmazott szimulációk típusai

Az alábbi szerkezeti analízis típusok fordulnak elő leggyakrabban szerszámgép konstrukciós folyamatok során:

- Statikai analizis: Időben állandó terhelés hatására létrejövő állandósult deformáció vagy feszültség számítására alkalmazható módszer. Az esetleges csillapítást és tehetetlenséget, vagyis az időfüggő terheléseket okozó elemeket nem veszi figyelembe.

- Modálanalizis: A vizsgált szerkezet rezgési karakterisztikájának, valamint az egyes sajátfrekvenciák meghatározására és lengésképeik ábrázolására alkalmas. Részletesebb dinamikai vizsgálatok (pl. tranziens dinamikai, harmonikus-, vagy spektrum analízis) alapvizsgálataként szolgálhat.

- Harmonikus válasz analízis: Időben ciklikusan változó gerjesztésre adott állandósult válasz meghatározására használható. A vizsgálat a terhelés kezdetén fellépő tranziens jellegü jelenségeket figyelmen kívül hagyja. Megjósolhatóvá válik általa a vizsgált szerkezet állandósult állapotú viselkedése, vizsgálható a kifáradás, valamint a rezonancia jelensége. A vizsgálat eredményét amplitúdó-frekvencia diagram formájában foglalja össze.

- Statikai és modálanalizis kombinációja: Ekkor statikus terhelés által előfeszített állapotú rendszer sajátfrekvenciáinak és lengésképeinek feltárása válik lehetővé. Fontossága abban rejlik, hogy a vizsgálatba vont rendszer előfeszített és előfeszítetlen állapotai jelentős mértékben eltérő sajátfrekvenciákat és lengésképeket tartalmaznak.

Bármilyen VEM-vizsgálat elvégzéséhez nélkülözhetetlen a vizsgált szerszámgép (egyszerüsített) 3D-s modellje, amelyet NX11 nevü tervezőrendszer segítségével készítettünk el, katalógusadatok és a tanszéki mühelyben megtalálható szerszámgép figyelembevételével. A 2. ábrán látható a gép 3D-s modellje, ami már parasolid formátumban, importált modellként jelenik meg az ANSYS modellterében, valamint ezzel párhuzamosan látható a hálózást követő állapotában.

\section{Modálanalízis}

Bármely valós fizikai rendszer rezgésbe jöhet, rezgő mozgást végezhet, és ilyenkor a rendszer tulajdonságainak tekinthetők a lehetséges szabad rezgések sajátfrekvenciái és a különféle rezgésképek (módusok).

Analitikus esetben a rendszer mechanikai modelljének felállítását követően, a matematikai modellt megoldva (a mozgást leíró differenciálegyenletet vagy differenciálegyenlet-rendszert) származtathatók a rendszer sajátfrekvenciái, és a hozzá kapcsolódó sajátalakok, amely feladatot most egy végeselem 
szoftver végez el a rendelkezésre álló bemeneti adatok (pl. 3D geometria, kényszerek, peremfeltételek, hálózás típusa, elemméret, csillapítási tényező, anyagminőség) alapján.
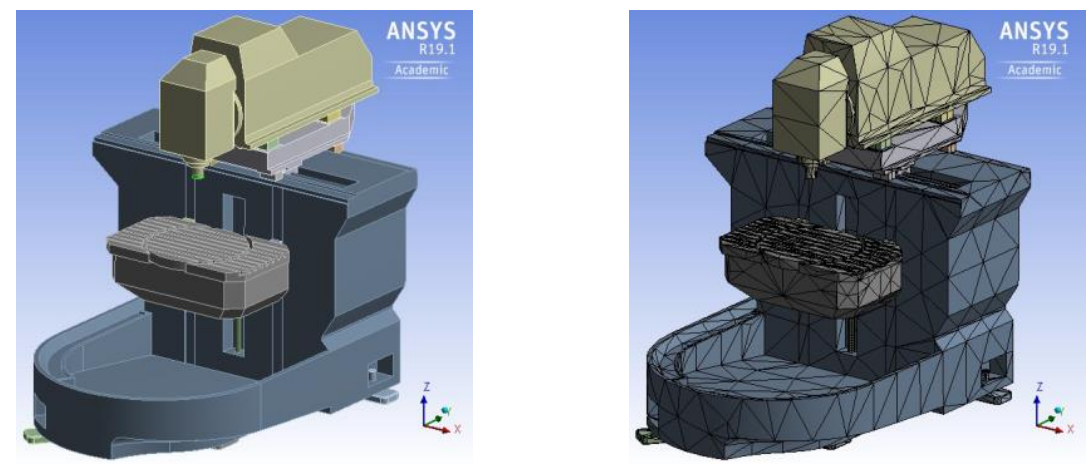

2. ábra. A vizsgált 3D-s modell importálást, és hálózást követöen

Az analízis során a 3D-s modellgeometria egészét véges méretủ elemekre bontjuk fel. Ezeknek az elemeknek a jellemzőit leíró mátrixokból építi fel a szerkezet egészére vonatkozó merevségi, tömeg és csillapítási mátrixokat. A mátrix módszer használata dinamikai rendszerek esetében az alábbi

$$
[M]\{\ddot{x}\}+[D]\{\dot{x}\}+[K]\{x\}=\{f\}
$$

differenciálegyenlet-rendszer felírásához vezet [3]. Az (1) egyenletrendszer - a végeselemek számától függően - igen nagyméretű is lehet így ennek megoldása csakis numerikus módszerekkel, jelentős számítási kapacitás megléte mellett lehetséges.

A vizsgálat föbb lépései:

1. A vizsgált megmunkáló központ 3D-s modelljének importálása ANSYS-ba.

2. A szimulációk típusainak kiválasztása, a vizsgálatok közötti kapcsolatrendszer kialakítása, mint ahogyan az 1. ábra mutatja.

3. Az ANSYS által a 3D-s geometria elemei között automatikusan létrehozott kapcsolatok, kapcsolódások vizsgálata, majd anyagminőség definiálása és hozzárendelése az egyes részegységekhez.

4. Hálózási beállítások, módszerek definiálása, majd a modell behálózása (2. ábra).

5. Kinematikai és dinamikai peremfeltételek megadása a modellen.

6. Szimuláció beállítások megadása: keresett módusok száma, módszer kiválasztása, csillapítás figyelembevétele, csillapítási tényező értéke, egyéb beállítások.

7. Szimuláció futtatása, a kapott eredmények értékelése.

A fenti lépések elvégzését követően az alábbi eredményeket kaptuk:

1. táblázat. A numerikus módon meghatározott sajátfrekvencia értékek

\begin{tabular}{ccccccccc}
\hline módus & 1 & 2 & 3 & 4 & 5 & 6 & 7 & 8 \\
\hline $\mathrm{f}[\mathrm{Hz}]$ & 108,16 & 132,98 & 159,49 & 229,01 & 325,65 & 379,22 & 538,34 & 663,45 \\
\hline
\end{tabular}

A szimuláció futtatását követően a program amellett, hogy meghatározza a keresett sajátfrekvenciák értékeit, megjeleníti az egyes sajátfrekvenciákhoz tartozó lengésképet is.

Az egyes anyagtípusokra vonatkozó csillapítási tényezők megadását követően, és a modálanalízis beállításaiban bekapcsolva a csillapítás figyelembevételére irányuló opciót, lehetőség nyílik a 
sajátfrekvenciák meghatározására csillapított esetben. Azonban számottevő változás nem figyelhető meg a kapott eredmények tekintetében, ugyanis a csillapítás hatása elsősorban az amplitúdó mértékének a csökkenésében nyilvánul meg, ahogy az gyakorlati szerszámgép vizsgálatok során is tapasztalható [4].

A szerszámgép egyes sajátfrekvenciájához tartozóan a 3. ábrán látható lengésképek jelennek meg. E lengésképek elemzése során célszerü meghatározni az egyes lengésképek domináns irányát, irányait, amelyekből a berendezés dinamikai merevségére következtethetünk, és amelynek a megmunkálási irányok kiválasztásában van fö szerepe [5].
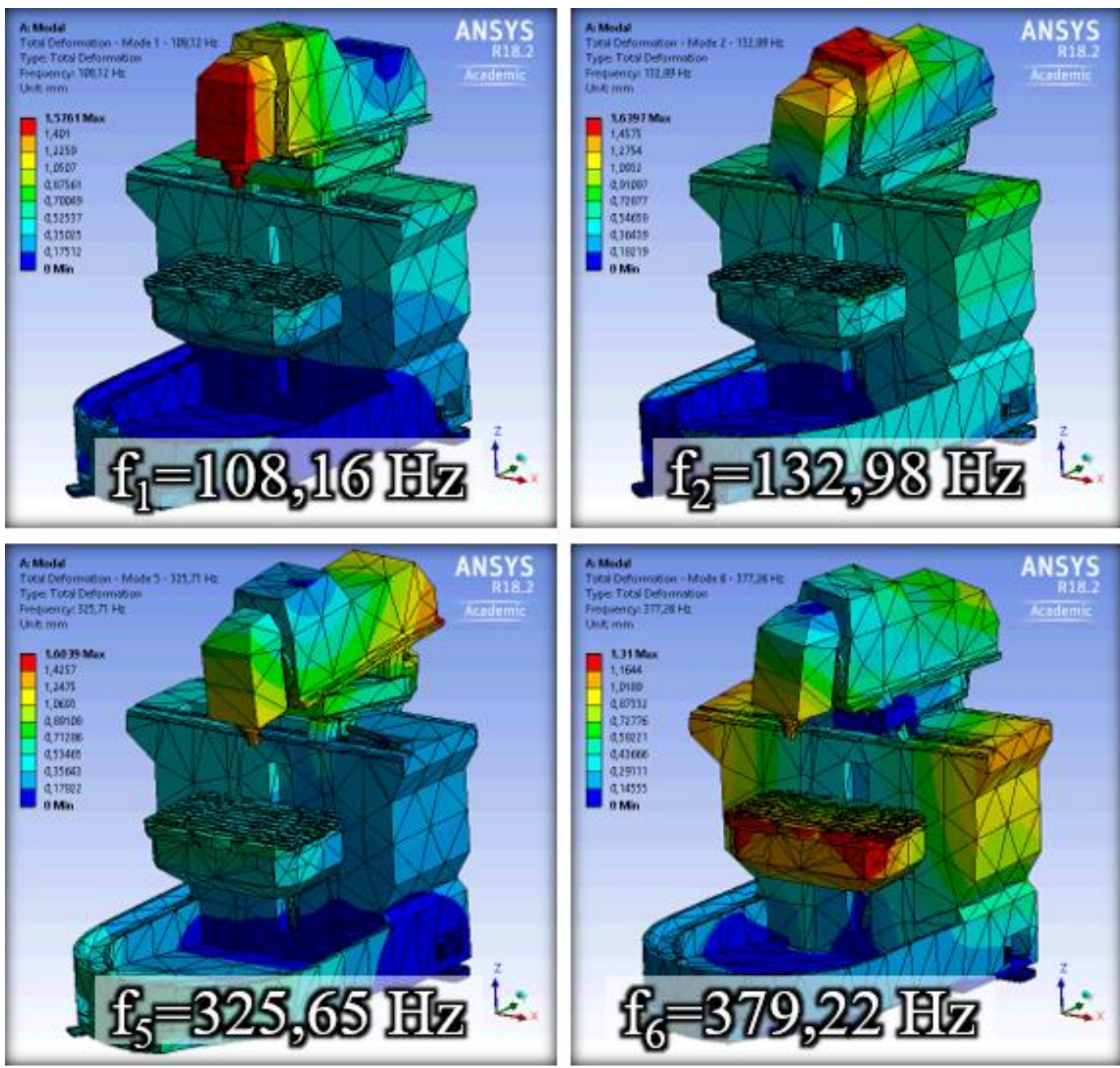

3. ábra. A modálanalizis eredményei - lengésképek (2/1.) 

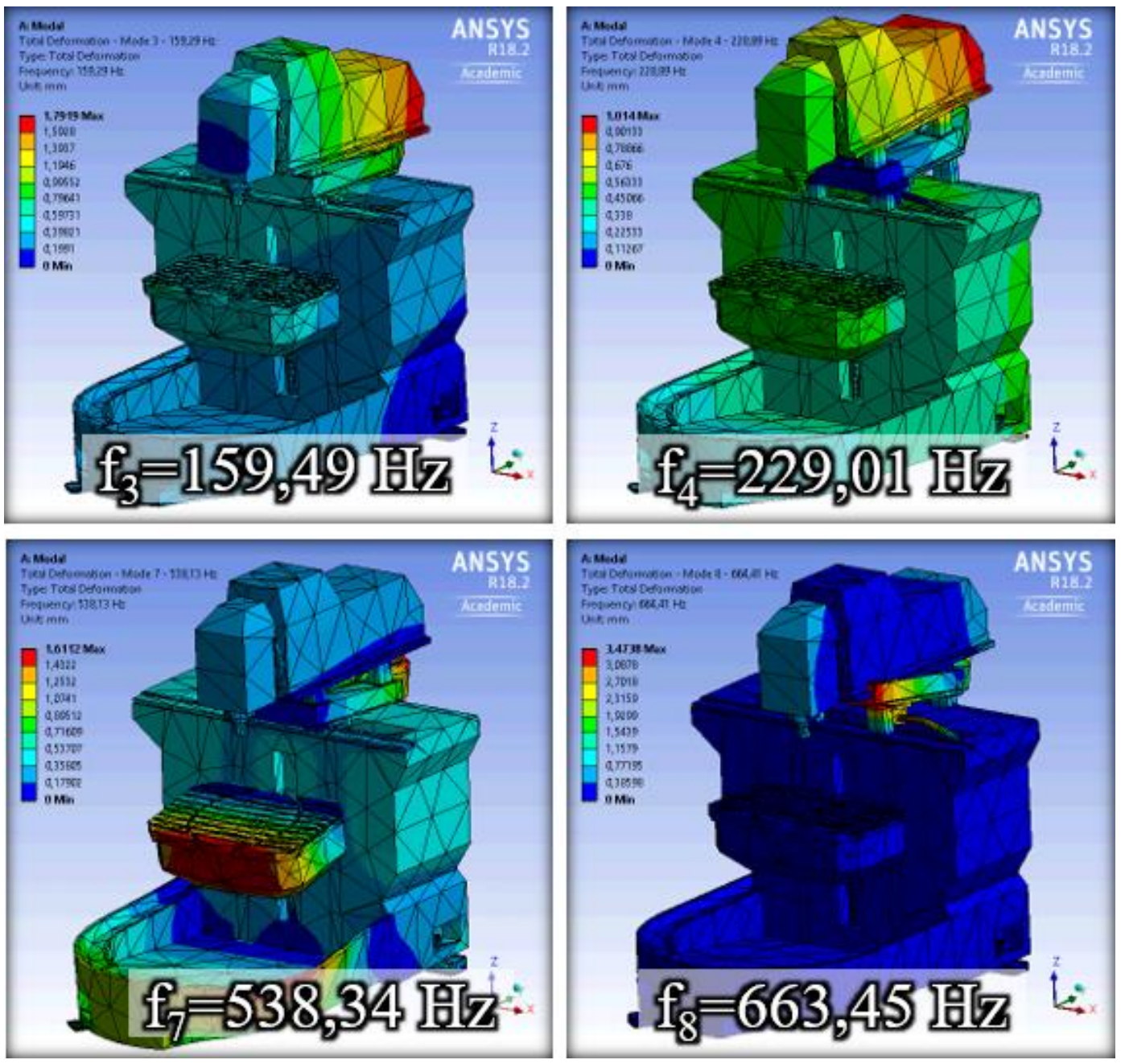

3. ábra. A modálanalízis eredményei-lengésképek (2/2.)

\section{3. Összefoglalás}

Jelen cikkben egy lehetséges módszert mutattunk be egy megmunkáló központ dinamikai merevségének (sajátfrekvenciáinak) a meghatározására. A CAE szoftverrel történő vizsgálat gyors és a valós viselkedést elfogadható mértékben megközelítő számítást tesz lehetővé megfelelő 3D-s modell megléte esetében és az egyes elemek anyagminőségének ismeretében. Az eredményeket tekintve a korábban analitikus úton számolt sajátfrekvencia értékek jól közelítik a szoftverrel kiszámolt adatokat. Továbbá a lengésképekből jól látszik, hogy a gép dinamikai merevsége z-irányban (függőlegesen) a leggyengébb, így függőleges irányú előtolást igénylő megmunkálások esetén szükséges megfontolni az alkalmazott megmunkálási paraméterek értékét. 


\section{Köszönetnyilvánítás}

A cikkben ismertetett kutató munka az EFOP-3.6.1-16-2016-00011 jelü „Fiatalodó és Megújuló Egyetem - Innovatív Tudásváros - a Miskolci Egyetem intelligens szakosodást szolgáló intézményi fejlesztése" projekt részeként - a Széchenyi 2020 keretében - az Európai Unió támogatásával, az Európai Szociális Alap társfinanszírozásával valósul meg.

\section{Irodalom}

[1] Kiss, R., Szilágyi, A.: Analysis of the dynamic behaviour of the CNC machine centre by FEM, DMS Journal, Miskolc, 2019. Február

[2] Kiss, R.: CNC megmunkáló központ dinamikai viselkedésének vizsgálata végeselemmódszerrel, Diplomaterv, Miskolc, 2019.

[3] Csernák, G., Stépán, G.: A műszaki rezgéstan alapjai. Egyetemi jegyzet, Budapest, BME, 2012.

[4] Dömötör, F.: Rezgésdiagnosztika I., Dunaújvárosi Főiskola, Dunaújváros, 2008.

[5] Pascal, M.: Parallelization of Design and Simulation: Virtual Machine Tools in Real Product Development. Doctoral Thesis, ETH Zürich, 2012. 